\title{
DEVELOPING STUDENT WORKSHEET OF TEMPERATURE AND HEAT BASED ON SCIENTIFIC PROCESS SKILL
}

\author{
Fharia Fhadhila*1, Candra Ertikanto ${ }^{2}$, Undang Rosidin ${ }^{3}$ \\ 1,2,3 Physics Education Department, Postgraduate Program, Universitas Lampung, Indonesia \\ ${ }^{*}$ Correspondence address: fhariaf@yahoo.com
}

Accepted: December 12 $2^{\text {th }}, 2017$. Approved: March 28 $8^{\text {th }}, 2018$. Published: April 29 $9^{\text {th }}, 2018$

\begin{abstract}
This research aims to develop a product in the form of Student Worksheet of temperature and heat based on Scientific Process Skills. The study was conducted within five stages: analysis, design, development, implementation, and evaluation. The results of the research showed that Student Worksheet's construct validity value of $80.30 \%$ and $70.96 \%$ of content validity. Student Worksheet has a questionnaire value of easiness of 3, 29, attractiveness of 3.32 and usefulness of 3.19. Student Worksheet effectively increases the average of the students' learning outcomes both in the cognitive domain of 80.00, affective domain of $81.30 \%$ and psychomotor domain of 80.81 . Based on the results of the research, it can be said that Student Worksheet achieved the goal of characteristics development i.e., possesses content validity and construct validity in the good category, user feedback questionnaire with the result of very easy to use, highly attractive and helpful, and the effectiveness of increasing the average students'learning outcomes in the very high category. For future studies, the researchers suggest that the Science Process Skill-based worksheets are not only applied to the temperature and heat material but can be applied to other branches of science.
\end{abstract}

(C) 2018 Physics Education, UIN Raden Intan, Lampung, Indonesia

Keywords: scientific process skills, student worksheet, temperature and heat

\section{INTRODUCTION}

Education is a very important necessity of life for humans; because the human education can be utilized to improve some potential through the learning process so that they can meet their needs (Diani, 2016). Management of education in the modern era is increasingly dependent on the qualification of the educators to use the resources that were available to overcome problems that are faced by learners, as well as to prepare lessons to foster the way of the learners' creative thinking with science and technology development orientation (Khairunisa, 2016).

The process of science is the way in which scientists develop products of sciences, therefore, to be able to do a qualify science process, skills of science process are required, while product knowledge to produce something from the process of science done by scientists involving Scientific Process Skills (Supriyatman \& Sukarno, 2014).

The use of scientific approach in the invention process is able to encourage the skills of students, one of them is Scientific Process Skills (Siahaan \& Suyana, 2010). (Nuraini, Karyanto, \& Sudaris, 2014), argues that Scientific Process Skills is also important in terms of teaching the students to proceed and work systematically to obtain their expectation.

One form of printed teaching materials that can be used in the learning process is the Student Worksheet. Student Worksheet is sheets contain tasks that must be done by learners. The use of student worksheet in learning is one of the efforts to be made to familiarize the behavior of scientists on the learners. Based on observations from several worksheets that circulate in the field contains a summary of the material and exercises, yet they do not train the 
students the process of investigation to find the concept.

Based on the results of the literature study and need analysis of the students in SMAN 1 Banjit which is one of the high schools in Way Kanan that have implemented the curriculum of 2013. The questionnaire results and interview in the field found that the students' low score of physics, the learning process only used textbooks and did not use materials such as worksheets, the study was only focused on teachers, and the laboratory activities are rarely carried out (Fharia \& Ertikanto, 2015).

Based on the explanation, Physics physics has not been supported by facilities among other books, worksheets, and instructional media. Besides as the media of learning that can help the students, Student Worksheet can also facilitate the learners' communication with the teacher with an orientation of Scientific Process Skills. One of the materials in physics is temperature and heat. it is one of the concepts of physics in accordance with the characteristics of the Scientific Process Skills approach. On the concept of temperature and heat, the students are required to observe changes in temperature on the thermometer, make hypotheses regarding heat transfer, interpret data between temperature and time which causes the change of forms, communicate the graph of form changes. In addition, the concept of temperature and heat phenomena often encountered in everyday life.

Based on this, the researchers intend to develop a Student Worksheet of the temperature and heat material based on the Scientific Process Skills approach. The aim of this research is to develop a product of Student Worksheet on the temperature and heat material based on Scientific Process Skills.

\section{THEORETICAL FRAMEWORK}

One of the abilities that must be owned by teachers or educators is to be able to carry out their professional tasks by understanding how students learn and how to organize the learning process. Thus the teachers or educators will be able to develop and shape the character of the learners and to understand how students are undergoing their learning activities. Reber (Sugihartono, 2007) defines learning in two senses. First, learning as a process of acquiring knowledge, and second to learn as an ongoing transformation of the creative ability as a result of enforced exercises.

Learning is the teachers' programmed activities in the instructional frame, to create active learning, which emphasizes the provision of learning resources Dimyati and Mudjiono (Sagala, 2011). In general, learning is a conscious effort made by an educator for the learners by providing appropriate instruction in accordance with other learning resources to achieve the desired goal (Trianto, 2007).

One of the factors of success in the learning process is the existence of teaching materials such as worksheets. One form of printed teaching materials that can be used in the learning process is the Student Worksheet (Assalma, Rahayu, $\&$ Sri, 2013). The student worksheet is the teaching materials that have been packaged in a way that the students are expected to learn the teaching material independently (Damayanti, Ngazizah, \& $K$, 2012). According to the study by (Purnamawati, Ertikanto, \& Suyatna, 2017), the use of inquiry-based Student Worksheet is effective to regenerate all higher-order thinking skills of the students.

Learning through the process skills approach enables students to cultivate scientific attitude to develop fundamental skills so that in the learning process, the students can understand the learned 
concepts, thus learning outcomes that include knowledge, skills, and attitudes as demands of the curriculum competence will be achieved (Subagyo, Wiyanto, \& Marwoto, 2009).

Scientific Process Skills are skills gained from exercising mental abilities, physical, social fundamentally as the motor toward the more advanced capacity (Rustaman, 2007). Also mentions the Scientific Process Skills are the scientific skills of the students when doing sciencebased activities to acquire concept and understanding (Budisetyawan, 2012).

Process Skills consists of a number of skills that cannot be separated from one another, but there is a special emphasis in each of these skills. Below in the table 1 are the sub-skills with the indicator process according to (Rustaman, 2007), namely:

Table 1 Scientific Process Skills and Indicators of the Scientific Process Skills

\begin{tabular}{|c|c|c|}
\hline No & $\begin{array}{c}\text { Scientific } \\
\text { Process Skills }\end{array}$ & $\begin{array}{l}\text { Indicators of the Scientific } \\
\text { Process Skills }\end{array}$ \\
\hline 1 & Observing & $\begin{array}{l}\text { - Using as many senses as } \\
\text { possible } \\
\text { - Collecting or using any of } \\
\text { the relevant facts }\end{array}$ \\
\hline 2 & $\begin{array}{l}\text { Grouping / } \\
\text { Classification }\end{array}$ & $\begin{array}{l}\text { - Taking notes of any } \\
\text { observations separately } \\
\text { - Taking notes of the } \\
\text { differences } \\
\text { similarities } \\
\text { - Contrasting traits } \\
\text { - comparing } \\
\text { - Finding basic grouping or } \\
\text { classification } \\
\text { - Connecting the observed } \\
\text { results }\end{array}$ \\
\hline 3 & interpreting & $\begin{array}{l}\text { - Connecting the observed } \\
\text { results } \\
\text { - Finding patterns in a series } \\
\text { of observations } \\
\text { - Concluding }\end{array}$ \\
\hline 4 & predicting & $\begin{array}{l}\text { - Using patterns of } \\
\text { observations } \\
\text { - Suggesting what might } \\
\text { happen on the } \\
\text { circumstances that have } \\
\text { not been observed }\end{array}$ \\
\hline 5 & Asking & - Asking what, how and \\
\hline
\end{tabular}

\begin{tabular}{|c|c|c|}
\hline No & $\begin{array}{c}\text { Scientific } \\
\text { Process Skills }\end{array}$ & $\begin{array}{l}\text { Indicators of the Scientific } \\
\text { Process Skills }\end{array}$ \\
\hline & question & $\begin{array}{l}\text { why } \\
\text { - Asking for clarification } \\
\text { - Asking the hypothesis } \\
\text { backgrounds }\end{array}$ \\
\hline 6 & hypothesizing & $\begin{array}{l}\text { - Knowing that there is } \\
\text { more than one possible } \\
\text { explanation for a } \\
\text { phenomena } \\
\text { - Be aware that some } \\
\text { explanation needs to be } \\
\text { verified by obtaining more } \\
\text { evidence or conducting } \\
\text { problem-solving }\end{array}$ \\
\hline 7 & $\begin{array}{l}\text { Research } \\
\text { Planning / } \\
\text { Experiments }\end{array}$ & $\begin{array}{l}\text { - Determining the tool/ } \\
\text { material/sources to be } \\
\text { used } \\
\text { - Defining variables or } \\
\text { deciding factors } \\
\text { - Determining what will be } \\
\text { measured, observed and } \\
\text { recorded } \\
\text { - Determining what will be } \\
\text { implemented in the form } \\
\text { of work steps }\end{array}$ \\
\hline 8 & $\begin{array}{l}\text { Using } \\
\text { Tools/ } \\
\text { Materials }\end{array}$ & $\begin{array}{l}\text { - Using tools/materials } \\
\text { - Knowing the reason for } \\
\text { why using the } \\
\text { tool/material } \\
\text { - Knowing how to use the } \\
\text { tool/material } \\
\text { - applying Concepts } \\
\text { - Using the concepts } \\
\text { learned in new situations } \\
\text { - Using the concept of the } \\
\text { new experience to explain } \\
\text { what was going on }\end{array}$ \\
\hline 9 & Predicting & $\begin{array}{l}\text { - Using patterns } \\
\text { observations } \\
\text { - Suggests what might } \\
\text { happen on the } \\
\text { circumstances that have } \\
\text { not been observed }\end{array}$ \\
\hline 10 & $\begin{array}{l}\text { Asking } \\
\text { question }\end{array}$ & $\begin{array}{l}\text { - Asking what, how and } \\
\text { why } \\
\text { - Asking for clarification } \\
\text { - Asking the hypothesis } \\
\text { backgrounds }\end{array}$ \\
\hline
\end{tabular}

\section{METHOD}

This study used ADDIE development model (Singh, 2009). This model consists of five main phases or stages, namely 1) 
Analysis, 2) Design, 3) Development, 4) Implementation, 5) Evaluation.

The design of product try-out through pretest-posttest control group design, this design was used to compare the progress of students after learning between experimental class control class. The research design is shown in the table 2 below (Sugiyono, 2013: 116)

Table 2 Nonequivalent pre-post control group design

\begin{tabular}{llll}
\hline Experiment & O1 & X1 & O2 \\
\hline Control & O3 & X2 & O4 \\
\hline
\end{tabular}

Information:

$\mathrm{X} 1$ : The treatments were learning through the use the worksheets that have been developed

X2 : Treatment was learning through a conventional worksheet

O1 : pretest to the experimental class

$\mathrm{O} 2$ : Posttest to the experimental class

$\mathrm{O} 3$ : pretest to the control class graders

O4 : Posttest to the control; class

\section{RESULTS AND DISCUSSION Analysis}

This research and development aim to develop teaching materials in the form of material Student Worksheet of temperature and heat material based on the Scientific Process Skills. At this stage, it is important to analyze the needs toward the developed product by analyzing the preliminary research result that had been done to two physics teacher and 33 students at the high school level through questionnaire and interviews.

Researchers conducted a preliminary study and analyzed information from the questionnaire related to student worksheet development and the implementation of Scientific Process Skills approach. The researcher conducted curriculum analysis to determine the appropriate product in line with the demands of the curriculum. Curriculum analysis would produce themes that were relevant to Core Competence and Basic Competence.

\section{Design}

Product developed is in the form of students worksheets. The student worksheet is one of the widely used teaching materials. However, worksheets that correspond to Scientific Process Skills have not been used by teachers yet. Therefore, the researchers decided to choose Student Worksheet as teaching materials to be developed. Researchers developed a worksheet that serves as a practical guide and a guide in observation (Praswoto, 2014).

Student Worksheet formats are developed in accordance with the steps of Scientific Process Skills. The learning through Scientific Process Skills was selected so that it could be in line with the purpose of development of the teaching materials in the form of worksheets. The draft of the developed worksheet includes the title "Students Worksheet through Science Process Skill Approach (Temperature and Heat)". In accordance with the title, the basic competencies that students must achieve are Basic Competence 4.8 namely, Planning and implementing experiments to investigate the thermal characteristics of a material, especially the capacity, and thermal conductivity. Learning objectives to be achieved by the students were written in the early part of the activities of the worksheet. The achieved objectives were adjusted with the activities. Procedures or students' learning activities in the use of worksheets were developed in accordance with the Scientific Process Skills approach.

\section{Development}

The third step is the interpretation of the planning. In this step, all the things that are planned in the development of the worksheet were conceived and designed so that a draft product was produced. In this step, the developed worksheet had been produced as the results of the development in accordance with the 
planning that has been done. The seen in Table 3. following description of the draft can be

Table 3 Description of the draft of the product

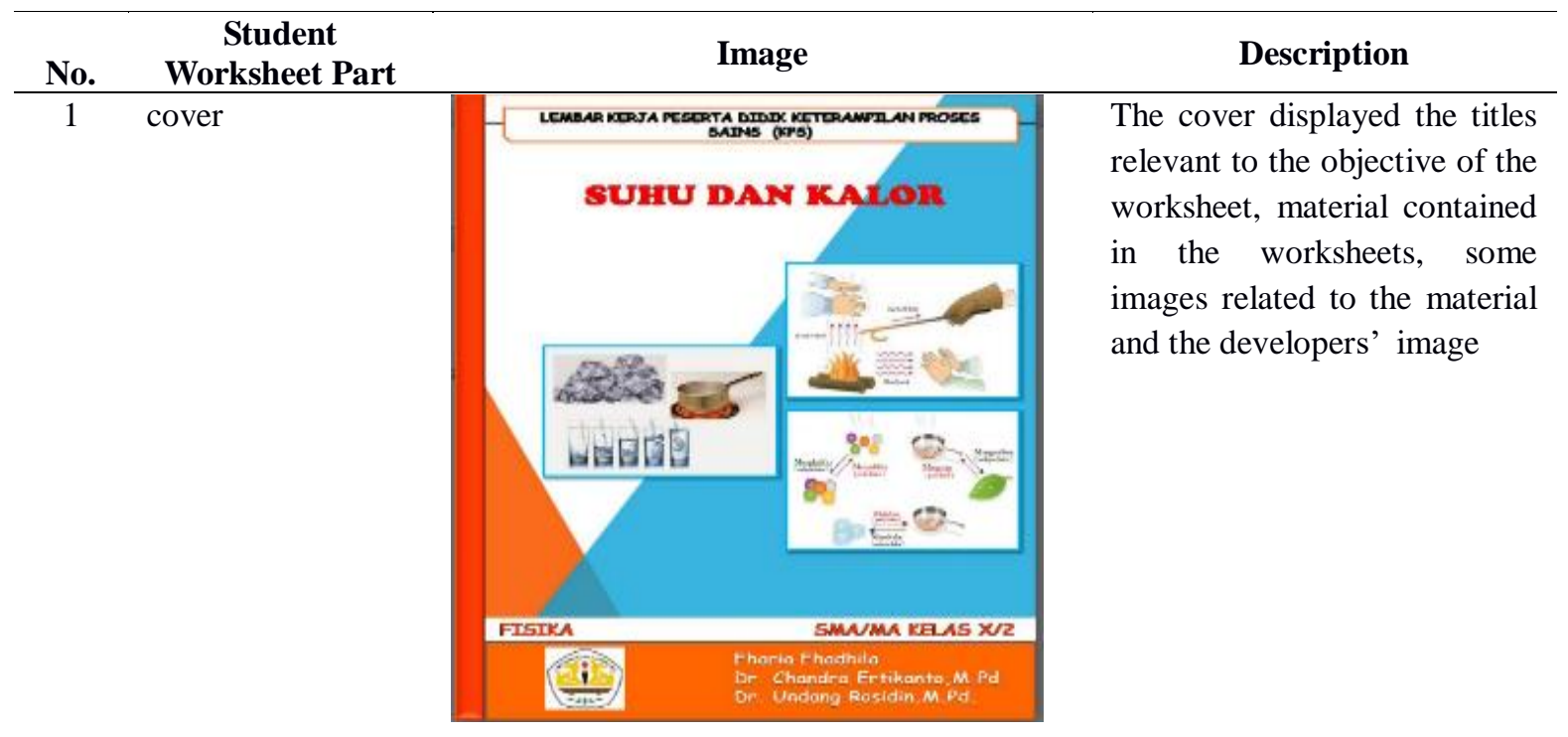

$2 \quad$ Preface

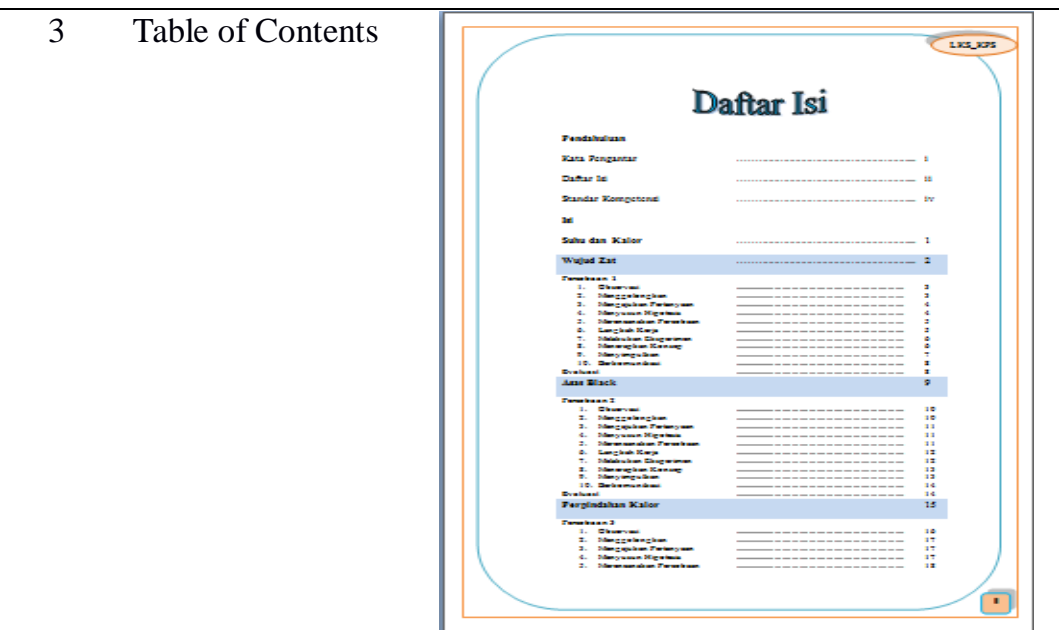

The preface is in the form of gratitude and thanks to the authors toward several parties that have supported the completion of the worksheet
This section showed the core competence and basic competence that should be met by the students after learning through temperature and heat material worksheet through Scientific Process Skills approach 


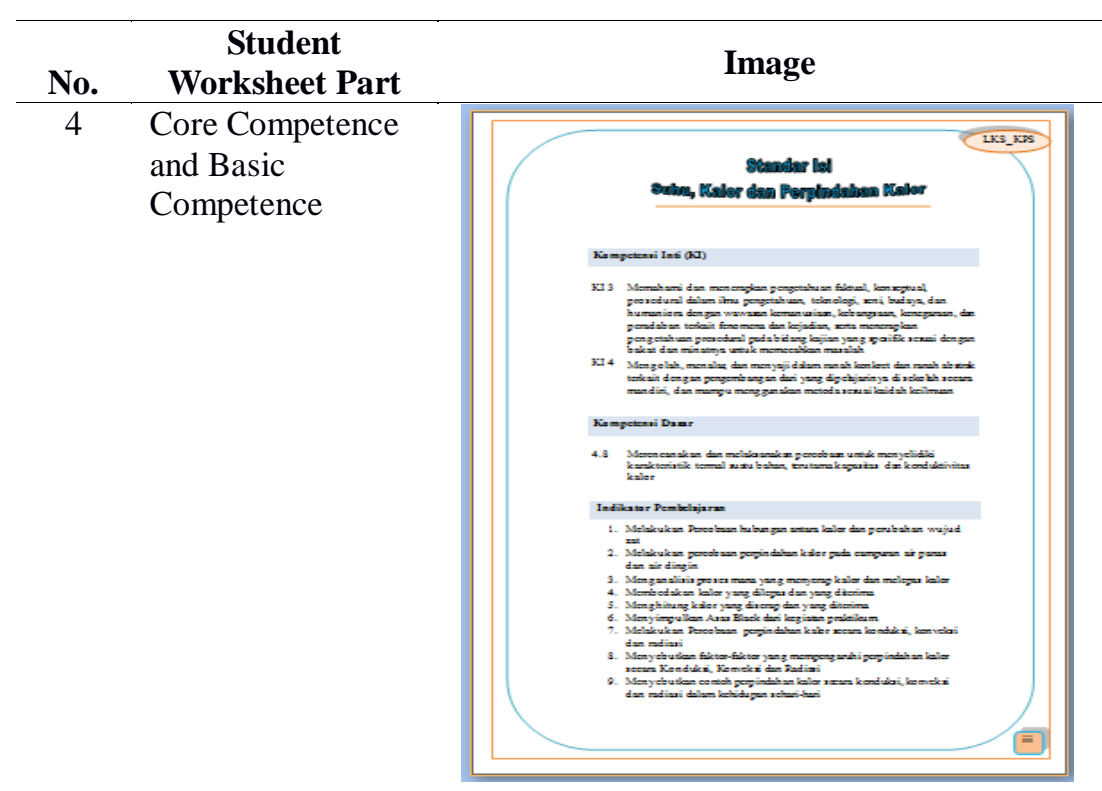

Description

This section showed the core competence and basic competence that should be met by the students after learning through temperature and heat material worksheet through Scientific Process Skills approach

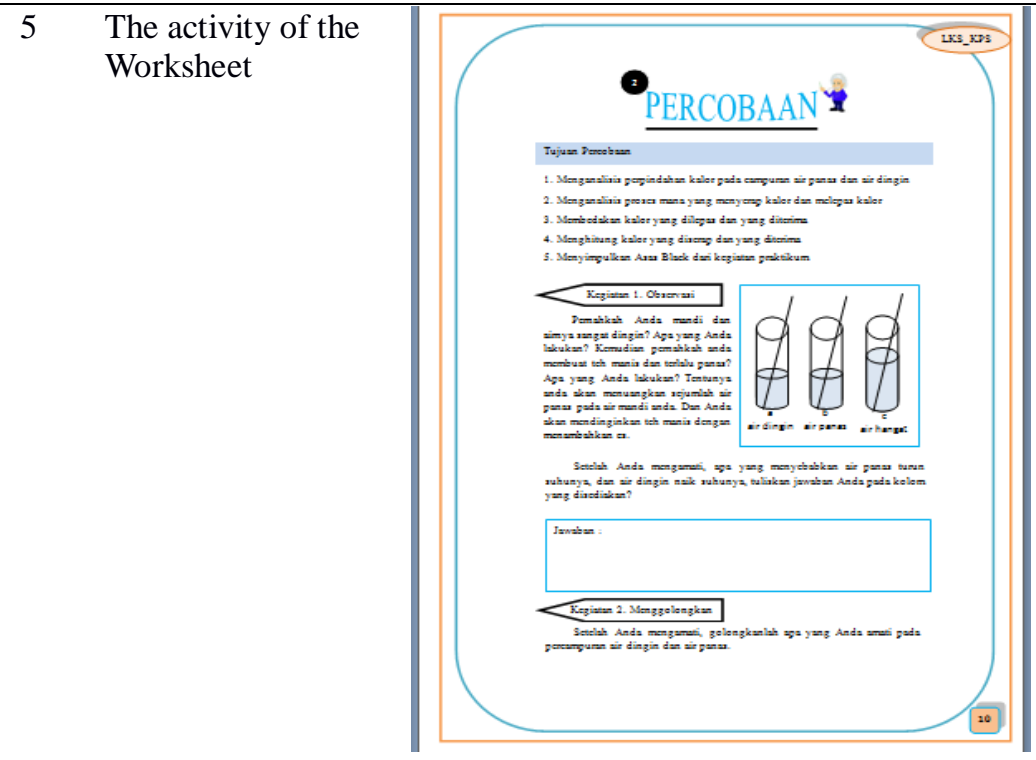

There are three experiments presented in the developed worksheet. The title of the experiment (1). Principle Black, (2). Substances and (3). Heat transfer. The worksheet was developed based on the indicators of Science Process Skill Approach:

(1) Observing

(2) Classifying

(3) Asking question

(4) Formulating hypothesis

(5) Planning experiment

(6) Determining the pace of work

(7) Conducting experiments

(8) Applying the concept

(9) Summing up and,

(10) communicating

One example of activities that are included in the worksheet.

\section{Implementation}

At this stage, validation or assessment to determine the propriety of the worksheets based on the construct and Content validity was conducted. The Worksheet's feasibility validation was done by two professors and one expert practitioner. Results of content validity and construct validity can be seen in Figure 1.

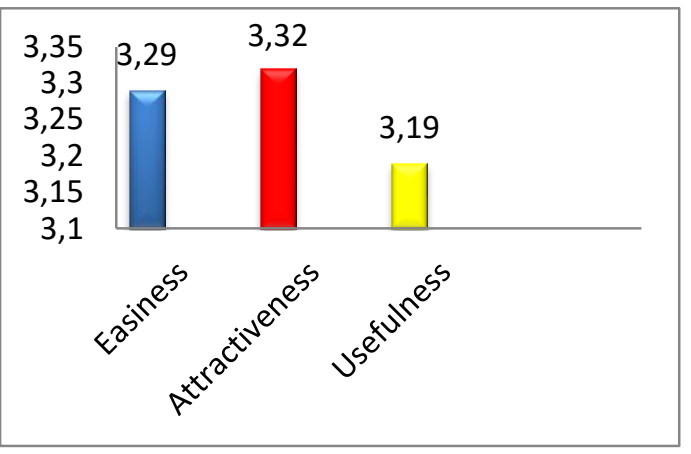

Figure 1 Graph of Content and Construct Validity Assessment. 
Based on the results of the expert, the value of the construct validity was $88.37 \%$ while the average value was 70.67 which fall into the good category. The value obtained through content validation was $75.96 \%$ while the average value of content validity was at 39.5 which fall into the good category. It can be concluded that the developed worksheet has been appropriate to be implemented as a teaching material.

\section{Evaluation}

This field testing aimed to evaluate the effectiveness and determine the responses of teachers and students toward the developed worksheet. The field testing of the worksheet was given to 34 students of class X Science 2 of SMA Negeri 1 Banjit. In this case, students were given the treatment in the form of learning materials using the Temperature and Heat worksheet developed by the researchers. Before implementing the worksheets, the students did a pretest to determine their score in Science Process Skill before implementing the worksheet. The implementation of Student Worksheet based on Scientific Process Skills Approach began with the stages of the indicators and explanations of then learning steps contained in the worksheet.

The statistical test used was Paired Sample t-test to determine whether there was an increase in the learning outcomes of students in the experimental class after implementing the developed worksheet and the test was also used to determine whether there was difference of the score of the students' Science Process Skill between the experimental class and the control class.

The analysis showed the Sig. (2 tailed) in Paired Sample T-Test was 0,000. Thus, Ho was rejected. This means that there was a significant improvement in the experimental class proved by higher score compared to the score of the students in the control class. Tests were carried out with the data analysis of Paired Samples t-test. Based on the analysis, it was shown that the Sig. (2 tailed) was $0.000<\alpha(0.005)$. Thus, it can be concluded that Ho was rejected, or the average score of students' posttest after learning using worksheet through Scientific Process Skills approach was higher than the pretest.

Based on the statistical analysis, the use of worksheet of temperature and heat material through Scientific Process Skills Approach toward the students of the tenth grade of SMA Negeri 1 Banjit was effective in improving the students' learning outcome.

After the suitability and feasibility of the product were known, then the product's field testing was conducted to the students to determine its effectiveness and to find out the responses of the students toward the product, the results of questionnaires showed that the easiness, attractiveness, and usefulness could be seen in Figure 2.

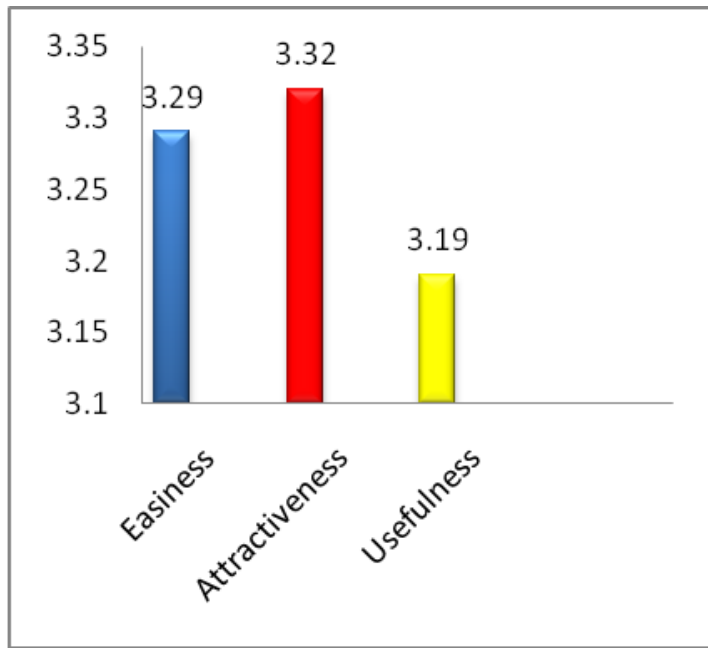

Figure 2 Recapitulation of questionnaire responses of the easiness, attractiveness, and usefulness

The results of student responses to the instructional materials of the Student Worksheet of Temperature and Heat material through Scientific Process Skills Approach were taken through questionnaires given to the teachers and students. Based on the results of the 
questionnaires, the developed worksheet was in the very easy, very attractive and very helpful category. The results of this research were in agreement with research (Tarmizi, 2010), students agreed that the application of Scientific Process Skills approach made the students understand the material easily. How the teacher presented the lessons with the application of Scientific Process Skills Approach was interesting. From the research and reference, it can be concluded that based the use of Student Worksheet through Scientific Process Skills approach was very easy, very interesting and very useful in the process of learning and teaching.

The results of students' score based on the average score of pre-test and posttest and the value of $\mathrm{N}$-gain showed that there was a significant difference. This result was found after being given different treatment; the experimental class used worksheet of temperature and heat through Scientific Process Skills Approach while the control class used the conventional worksheet. The calculation result of the value of $\mathrm{N}$-gain for both classes can be seen in Table 4 .

Table 4. Results of N-gain learning outcomes

\begin{tabular}{ccc}
\hline Class & $\begin{array}{c}\text { Average - } \\
\text { Average N- } \\
\text { gain }\end{array}$ & categories \\
\hline Control & 0.40 & moderate \\
Experiment & 0.71 & High \\
\hline
\end{tabular}

The results of the calculation, the average value of the $\mathrm{N}$-gain in the experimental class was 0.71 which is in the category of Moderate and the average value of the $\mathrm{N}$-gain of the control class was 0.40 which is in the high category. To determine the difference in value between the experimental class and the control class, a hypothetical test was employed.

The result of the hypothetical test calculation showed that there are differences in the score of the students in the experimental class compared to the students in the control class. The second effectiveness test was the difference score of pretest and posttest of the experimental class.

Based on the second effectiveness test, it can be concluded that the average of posttest score of the students who learned using worksheet of temperature and heat through Scientific Process Skills Approach was higher than their pretest score. Results from both hypothetical tests can be concluded, the use of worksheet of temperature and heat through Scientific Process Skills Approach could increase the result of cognitive learning where the students usually just act as listeners or just observe the teacher explanation of the subject, the process of learning through the use of worksheet of temperature and heat through Scientific Process Skills Approach, the students could carry out the learning activities with indicators of Scientific Process Skills Learning that have already contained in the worksheet.

In the process of learning using the worksheets through Scientific Process Skills approach students can be included in the process of teaching and learning as if the students are conducting scientific activities, namely observing, classifying, posing questions, drawing up hypotheses, planning experiments, determining the procedures, experimenting, applying the concepts, concluding and communicating.

Affective assessment result obtained from observation sheet for the experimental and control classes. The average score of the two classes of the assessment can be seen in Table 5 .

Table 5. Summary of Affective assessment

\begin{tabular}{ccc}
\hline Class & Average & categories \\
\hline Control & 59.85 & Low \\
Experiment & 81.30 & Very High \\
\hline
\end{tabular}

Based on the average score of attitude assessment, it can be concluded that the experimental class attitude was higher than the control class. This was because the experimental class used 
worksheet of temperature and heat materials with the Science Process approach can train students' scientific attitude by showing the admiration of the greatness of God the Almighty, by showing gratitude and expressing admiration to the greatness of God the Almighty, doing the activities in the worksheet, taking care of the tools and materials well, not damaging tools and materials, able to provide ideas in solving problems. Being able to design issues according to theory and appreciate friends' opinions, accepting friends' opinions, and thinking broadly.

The results of psychomotor or skill assessments were obtained using psychomotor observation sheets. The results of the skills assessment for the experimental and control classes. The average result of skill assessment of the two classes can be seen in Table 6 .

Table 6. Result of psychomotoric assessment

\begin{tabular}{ccc}
\hline Class & Average & categories \\
\hline Control & 57.32 & Low \\
Experiment & 80.81 & Very High \\
\hline
\end{tabular}

Based on the result of the average attitude assessment, it can be concluded that the experimental class had a higher mean score than the control class. This is because of the experimental class use worksheet of temperature and heat materials through Scientific Process Skills approach. It can train skills such as designing experimental tools and materials, identifying problems, illustrating the problem, and summarizing the results of experiments. The result of worksheet development of temperature and heat materials with the Scientific Process Skills approach in terms of the effective, psychomotor, and cognitive domains can be seen in Figure 3.

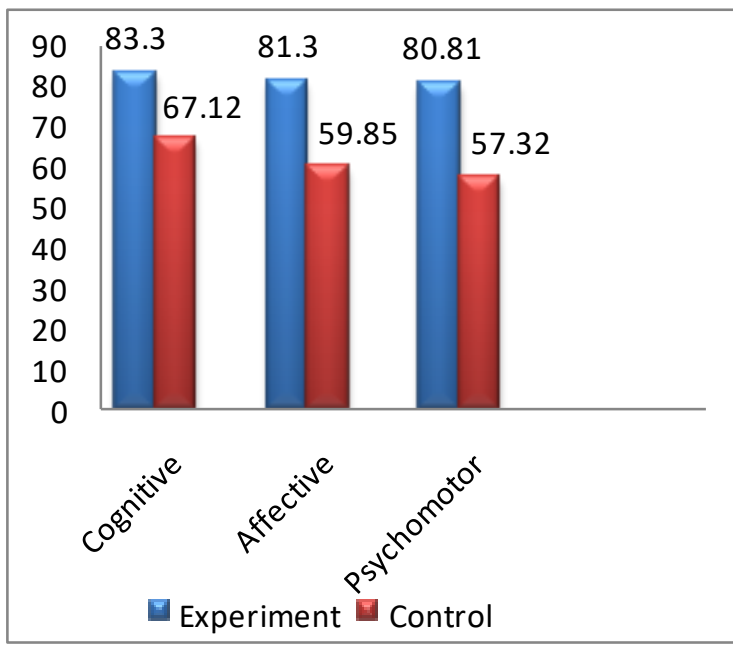

Figure 3 Recapitulations of the score of cognitive, affective and psychomotor

Based on the result of the research of the three domains, it can be concluded that the average score of the experimental class was higher than the control class. So the use of worksheet of temperature and heat material through Scientific Process Skills Approach could increase cognitive, affective and psychomotor. (Nisa \& Suliyansah, 2014) state that the cognitive aspects determine the students' cognitive learning outcomes in the experimental class was better than the control class. In the experimental class, it was also obtained the score of science process skill that the science process skill in students is good and the skills that need to be taught and trained more were science process skill in making hypothesis, drawing a conclusion, experimenting, and analyzing the data.

Scientific process skills and its influence on students' learning outcomes emphasizes Scientific process skills in one science lesson means giving students the opportunity to solve their own problems that become the topic of learning by doing the activities in the worksheet based on the Scientific process skills indicators. The results of the Scientific process skills assessment of the experimental class and control class can be seen in Figure 4. 


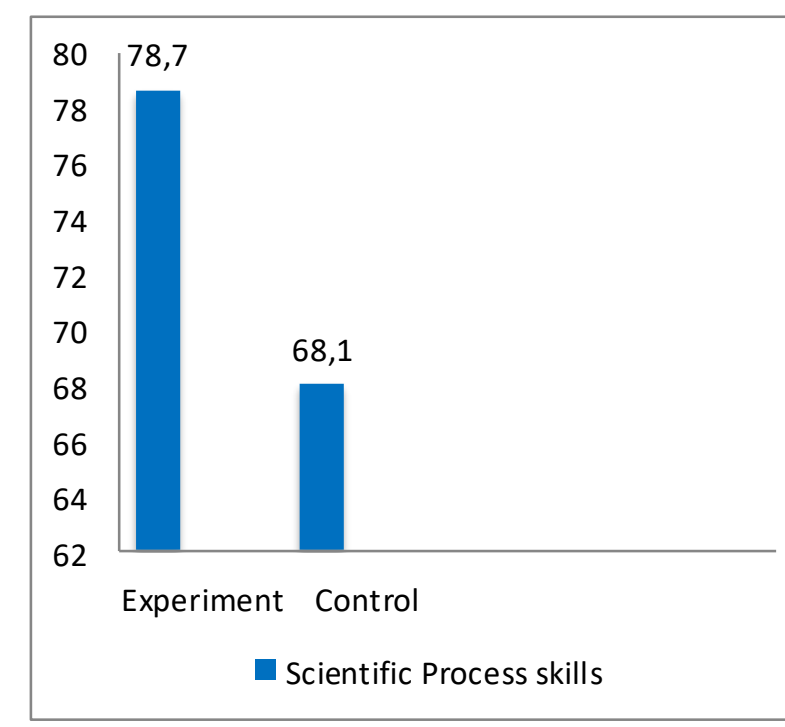

Figure 4 Assessment of Scientific Process skills

Based on the result, the experimental class was higher than the control class, this was because in the experimental class the students are trained independently to conduct experiments with the stages of Scientific Process Skills Approach, where students perform activities of observing, classifying, asking questions, making hypotheses, planning experiments, determining work procedure, experimenting, applying concepts, concluding and communicating.

Based on the (Anita, Jalmo, \& Yolida, 2015) research results, the result of the experiments was seen on average $\mathrm{N}$-gain of Scientific Process Skills Approach of the experimental class students were higher than the control class. The increase in Scientific Process Skills Approach can also be seen in the analysis of students' responses toward the worksheet based on the increase of each indicator. According to (Khayota, Sitti, \& Sonnsusap, 2015) Scientific Process Skills Approach is required by students when conducting a scientific inquiry or during the learning process. Thus, it can be concluded that the Scientific Process Skills are very important in science learning.

Based on the analysis of experimental class through worksheet of temperature and heat materials based on Scientific Process Skills Approach was good. It can be seen from the average of experiment class percentage which is $78,70 \%$.

\section{CONCLUSION}

Based on the results of the research and discussion, it is concluded that the developed worksheet construct validity value of $80.30 \%$ and content validity value of $70.96 \%$ that fall within the good category. Student Worksheet's questionnaire gained 3.29 for easiness, 3.32 for attractiveness and 3.19 for usefulness which is in the very easy category, very interesting and useful. The worksheet was effective in increasing the average of student learning outcomes in the cognitive domain of 80.00 , affective of 81.30 and psychomotor of 80.81 which are in the very high category.

\section{SUGGESTION}

Based on the result of the research, the researchers suggest that Student Worksheet based on scientific Process Skills should not be only applied to temperature and heat material, but can be applied with other branches of science. Teachers are expected to intensify their role as facilitators when learning in the classroom so that the allocation of available time can be utilized well.

\section{REFERENCES}

Anita, I., Jalmo, T., \& Yolida, B. (2015). Pengembangan LKS Berbasis Keterampilan Proses Sains (KPS) Untuk Meningkatkan KPS Siswa. Pendidikan Biologi.

Assalma, N. E., Rahayu, E. S., \& Sri, R. (2013). Pengembangan Lembar Kerja Siswa Dengan Pendekatan Pembelajaran Berbasis Proyek (PBP) Dan Berwawasan Salingtemas. Unnes Journal of Biology Education, 2(1), 1-9.

Budisetyawan, S. (2012). Pengembangan 
LKS IPA Terpadu Berbasis Inkuiri Terbimbing pada Tema Sistem Kehidupan dalam Tumbuhan Kelas VIII di SMPN 2 Playen. Jurnal IPA FMIPA UNY, 1(4), 1-6.

Damayanti, D. S., Ngazizah, N., \& K, E. S. (2012). Pengembangan Lembar Kerja Siswa (LKS) Dengan Pendekatan Inkuiri Terbimbing. Jurnal Progam Studi Pendidikan Fisika Universitas Muhammadiyah Purworejo, 3(1), 1-5.

Diani, R. (2016). Pengaruh Pendekatan Saintifik Berbantukan LKS Terhadap Hasil Belajar Fisika Peserta Didik Kelas XI SMA Perintis 1 Bandar Lampung. Jurnal Ilmiah Pendidikan Fisika Al-BiRuNi, 5(1), 83-93.

Fharia, F., \& Ertikanto, C. (2015). Analisis Kebutuhan Pembelajaran Suhu dan Kalor dengan Pendekatan Keterampilan Proses Sains. Seminar Nasional Pendidikan MIPA Fakultas Keguruan dan Ilmu Pendidikan. Bandar Lampung: Universitas Lampung.

Khairunisa. (2016). Analisis Keteramilan roses Sains Fisika di Kabupaten Jeneponto. Jurnal Pendidikan Fisika Universitas Muhammadiyah Makassar, 5(3), 1-10.

Khayota, J., Sitti, S., \& Sonnsusap, K. (2015). The Curriculum Development for Science Teacher's Training: The Action Lesson Focusing on Science Proses Skills. Education Research Dan Reviews, 10(23).

Nisa, C. N., \& Suliyansah. (2014). Pengaruh Penerapan Pembelajaran Penemuan Terbimbing Dengan Mengintegrasikan Keterampilan Proses Sains Terhadap Hasil Belajar Siswa SMP Negeri 1 Kamal. Jurnal Inovasi Pendidikan Fisika (JIPF), 3(1), 1-5.

Nuraini, N., Karyanto, P., \& Sudaris, S. (2014). Pengembangan Modul Berbasis POE (Predict, Observe, and Explain). Universitas Sebelas Maret.

Praswoto, A. (2014). Pengembangan Bahan Ajar Tematik. Yogyakarta: Kencana Media Group.

Purnamawati, D., Ertikanto, C., \& Suyatna, A. (2017). Keefektifan Lembar Kerja Siswa Berbasis Inkuiri Untuk Menumbuhkan Keterampilan Berpikir Tingkat Tinggi. Jurnal Ilmiah Pendidikan Fisika Al-BiRuNi, 6(2), 209-219.

Rustaman. (2007). Keterampilan Proses Sains. Bandung: SPS UPI.

Sagala, S. (2011). Konsep dan Makna Pembelajaran. Bandung: Alfabeta.

Siahaan, P., \& Suyana, I. (2010). Hakekat Sains dan Pembelajarannya. Bandung.

Singh, O. B. (2009). Development and Validation of a Web-Based Module to Teach Metacognitive Learning Strategies to Students in Higher Education. A dissertation submitted in partial fulfillment of the requirements for the degree of Doctor of Philosophy Department of Secondary Education College of Education University of South Florida. University of South Florida.

Subagyo, Y., Wiyanto, \& Marwoto, P. (2009). Pembelajaran Dengan Pendekatan Keterampilan Proses Sains Untuk Meningkatkan Penguasaan Konsep Suhu Dan Pemuaian. Jurnal Pendidikan Fisika Indonesia, 5, 42-46.

Sugihartono. (2007). Psikologi Pendidikan. Yogyakarta: UNY Press.

Supriyatman, \& Sukarno. (2014). Improving Science Process Skills (SPS) Science Concepts Mastery (SCM) Prospective Studen Teachers Through Inquiry Learning Instruction Model By Using Interactive Computer Simulation. International Journal of Science and Research (IJSR), 3(2), 6-9.

Tarmizi. (2010). Ketuntasan Belajar 
Siswa Melalui Penerapan

PendekatanKeterampilan Proses

PadaKonsepSistem Gerak Tumbuhan

di SMANegeri 3 Pidie. Jurnal

Pendidikan Biologi, 1(2), 50-58.

Trianto. (2007). Model Pembelajaran

Terpadu Konsep, Strategi dan

Implementasi dalam Kurikulum

Tingkat Satuan Pendidikan (KTSP).

Jakarta: Bumi Aksara. 